\title{
The broad clinical spectrum of hereditary neuropathy with liability to pressure palsy (HNPP)
}

\author{
O amplo espectro clínico da neuropatia hereditária com suscetibilidade à pressão
}

Osvaldo JM Nascimento

Universidade Federal

Fluminense - UFF Department of

Internal Medicine / Neurology Rio

de Janeiro, Brazil

Correspondence:

Osvaldo JM Nascimento, MD,

PhD, FAAN; Rua Siqueira Campos,

53/1204, 22031-071, Rio de Janeiro,

RJ, Brazil;

E-mail: osvaldo_nascimento@

hotmail.com

Conflict of interest:

There is no conflict of interest to

declare.

Received 19 Janury 2016

Accepted 21 January 2016

\section{(c) BY}

$\mathrm{H}$ ereditaty neuropathy with liability to pressure palsy (HNPP) is an autosomal dominant neuropathy encompassing a broad clinical phenotype spectrum, which usually makes its diagnosis difficult in an exclusive clinical basis. Recurrent sensory and motor neuropathy in a single nerve beginning in adolescence or young adulthood is characteristically seen. In most cases this recurrent clinical evolution is due to a PMP22 gene deletion. Mononeuropathies resulting from nerve pressure in entrapment points are the most common presentation, but an almost symmetric polyneuropathy can eventually be seen ${ }^{1}$. Suggestive electrophysiological findings that draw attention for HNPP diagnosis are in consideration. DNA mutations tests are diagnostic, but not always available.

Although it is an autosomal dominant condition, family history can be lacking in many cases, especially in Brazil, a country with a strong migration process and with different ethnics groups. In a recent comparison of causes of neuropathy in peripheral neuropathy reference centers in the United State of America and South-America (NA-SA project) we have observed a higher percentage of diagnoses of inherited neuropathies in the USA in comparison with Brazil: NA 292 (26.7\%), SA $103(10 \%)^{2}$. In an American international reference center of inherited neuropathy an epidemiological study, including 787 Charcot-Marie-Tooth disease (CMT) patients, showed that only $67 \%$ received molecular diagnosis ${ }^{3}$. This result points that the diagnosis is performed mainly in clinical/ neurophysiological basis.

This edition of Arquivos de Neuropsiquiatria includes an elegant study by Oliveira et al. ${ }^{4}$ reporting the clinical and neurophysiological features of HNPP due to the 17p11.2 deletion in 39 Brazilian patients, looking for its diagnostic characteristics. In this series, family history was present in $59 \%$ of cases, showing that clinical presentation, recurrence of signs and symptoms, and neurophysiological findings are strong elements for diagnostic suspicion. A progressive course is uncommon, but was reported in $20 \%$ of their HNPP patients ${ }^{4}$. Older presentation of HNPP was seen in this series, in contrast with others. The first clinical manifestation was the classical painless muscle weakness with at least one episode of acute nerve paralysis (61,5\% of cases). This painless acute or subacute mononeuropathy is the classical phenotype ${ }^{1}$. Pes cavus and nerve thickening, seen in CMT patients, was rare in Oliveira et al. ${ }^{4} \mathrm{HNPP}$ series. Heterogeneity in clinical presentation and disease course is the rule in this neuropathy ${ }^{1,5}$. Atypical presentations of HNPP, as generalized weakness and cramps, chronic ulnar neuropathy, carpal tunnel syndrome, CMT phenotype, and Guillain-Barré-like syndrome, were included in the 74 patients series of Luigetti et al. ${ }^{6}$, comprising $56 \%$ of cases. In this Italian series the typical presentation of recurrent multiple mononeuropathies was not prevalent, occurring in only $44 \%$ of patients 6 .

In a series of 12 children with confirmed PMP22 gene deletion, and correlating with the literature review, it was observed that peroneal palsy was the most common presentation (42\%), followed by brachial plexus palsy in $25 \%$ of cases. In $60 \%$ of the performed nerve conduction studies patterns suggestive of HNPP diagnosis were: multifocal demyelination at the entrapment site, generalized sensorimotor polyneuropathy, and a combination of the two first patterns ${ }^{7}$.

Transient sensory phenomena without weakness is referred by some patients, mainly when assuming some usual positions, as crossing legs. Paresthesia was the presenting symptom in $11 \%$ of Oliveira et al. ${ }^{4}$ cases, and positional sensory symptoms were present in $31 \%$. Interesting is the occurrence of pain as the presentation symptom of neuropathy in this series (15\% of cases), 
making the authors call attention to the fact that pain symptoms do not exclude HNPP diagnosis ${ }^{4}$. Sciatic neuropathy as the clinical presentation of HNPP has been reported ${ }^{8}$. Other clinical findings, including those reported in a small number of cases are included in the HNPP review reported by Bird ${ }^{9}$.

As usually observed in HNPP, the electrophysiological features are much more homogeneous, characterized by an asymmetric sensorimotor neuropathy with focal slowing observed in $94 \%$ of cases, including a case with brachial plexus pattern in Oliveira et al. ${ }^{4}$ series. Luigetti et al. ${ }^{6}$ considered the neurophysiological examination as the main tool for a proper diagnosis of HNPP. Sural nerve biopsy was performed in 12 patients in the Italian series, with ages ranging from 18 to 80 years old. Thickened myelin sheath related to the diameter of axon, corresponding to tomaculae was seen in semithin section in 6 cases, but teased fiber analysis disclosed tomaculae, the pathological hallmark of HNPP, in all specimens ${ }^{6}$. Nerve biopsy is an invasive and expensive procedure, and therefore should be indicated exclusively in selected cases.
CMT genes testing are not cost effective and are still unavailable in most centers in the world, including Brazil. Based on family history, clinical and electrophysiological findings there may be a guide pointing to which gene to test for mutations in CMT patients. Request a genetic test for CMT was considered in a "hit rate" - defined as the number of positive results for a particular gene when ordered ${ }^{10}$. PMP22 duplication (CMTIA)/deletion (HNPP) had the highest "hit rate" $(80 \%)$ in ordering gene testing (number of times ordered 40; number of hits 32), based on family history, clinical and electrophysiological findings ${ }^{10}$. Oliveira et al. ${ }^{4}$ clinical and electrophysiological findings reported in this issue of Arquivos de Neuropsiquiatria are also very useful for the diagnosis of HNPP, and to more accurately appeal a genetic test for HNPP, when available.

It is very important to make the diagnostic approach of HNPP based on clinical grounds. An appropriate genetic counseling and appropriate patient care should be early applied to avoid sequelae in some cases.

\section{References}

1. Pareyson D, Scaioli V, Taroni F, Botti S, Lorenzetti D, Solari A et al. Phenotypic heterogeneity in hereditary neuropathy with liability to pressure palsies associated with chromosome 17p11.2-12 deletion. Neurology. 1996;46(4):1133-7. doi:10.1212/WNL.46.4.1133

2. Pasnoor M, Nascimento OJ, Trivedi J, Wolfe GI, Nations S, Herbelin L et al. North America and South America (NA-SA) neuropathy project. Int J Neurosci. 2013;123:563-67. doi:10.3109/00207454.2013.782026

3. Saporta MA. Charcot-Marie-Tooth disease and other inherited neuropathies. Continuum (Minneap Minn). 2014;20 (5 Peripheral Nervous System Disorders):1208-25. doi:10.1212/01.CON.0000455885.37169.4C

4. Oliveira APM, Pereira RC, Onofre PT, Marques VD, Andrade GB, Barreira AA et al. Clinical and neurophysiological features of the hereditary neuropathy with liability to pressure palsy due to the 17p11.2 deletion. Arq Neuropsiquiatr 2016;74(2):99-105.

5. Mouton P, Tardieu S, Gouider R, Birouk N, Maisonobe T, Dubourg O et al. Spectrum of clinical and electrophysiologic features in HNPP patients with the 17p11.2 deletion. Neurology. 1999;52(7):1440-6. doi:10.1212/WNL.52.7.1440
6. Luigetti M, Del Grande A, Conte A, Lo Monaco M, Bisogni G, Romano A et al. Clinical, neurophysiological and pathological findings of HNPP patients with 17p12 deletion: a single-centre experience. J Neurol Sci. 2014;341(1-2):46-50. doi:10.1016/j.jns.2014.03.046

7. Chrestian N, McMillan H, Poulin C, Campbell C, Vajsar J. Hereditary neuropathy with liability to pressure palsies in childhood: case series and literature update. Neuromuscul Disord. 2015;25(9):693-8. doi:10.1016/j.nmd.2015.06.463

8. Topakian R, Wimmer S, Pischinger B, Pichler R. Hereditary neuropathy with liability to pressure palsies presenting with sciatic neuropathy. BMJ Case Rep. 2014;2014. doi:10.1136/bcr-2014-206883

9. Bird TD. Hereditary neuropathy with liability to pressure palsies. In: Pagon RA, Adam MP, Ardinger HH, Wallace SE, Amemiya A, Bean LJH et al, editors. GeneReviews ${ }^{\circledR}$ [Internet]. Seattle: University of Washington Seattle; 1993-2015.

10. Saporta AS, Sottile SL, Miller LJ, Feely SM, Siskind CE, Shy ME. Charcot-Marie-Tooth disease subtypes and genetic testing strategies. Ann Neurol. 2011;69(1):22-33. doi:10.1002/ana.22166 